$5-2021$

\title{
Self-Regulatory Effects of Performance Management System Consistency on Employee Engagement: A Moderated Mediation Model
}

\section{Shiva Kakkar}

Indian Institute of Management, Nagpur

Neharika Vohra

Indian Institute of Management, Ahmedabad

\section{Recommended Citation}

Kakkar, Shiva and Vohra, Neharika (2021) "Self-Regulatory Effects of Performance Management System Consistency on Employee Engagement: A Moderated Mediation Model," American Business Review. Vol. 24 : No. 1 , Article 11.

DOI: 10.37625/abr.24.1.225-248

Available at: https://digitalcommons.newhaven.edu/americanbusinessreview/vol24/iss1/11 
Self-Regulatory Effects of Performance

Management System Consistency on Employee Engagement: A Moderated Mediation Model
American Business Review

May 2021, Vol.24(1) 225 - 248

(c) The Authors 2021, CC BY-NC

ISSN: $2689-8810$ (Online)

ISSN: 0743-2348 (Print)

\author{
Shiva Kakkar ${ }^{\mathrm{a}}$ and Neharika Vohrab
}

https://doi.org/10.37625/abr.24.1.225-248

\begin{abstract}
The study investigates the influence of performance management system consistency on employee work engagement. Drawing on the 'job demands-resources model' and 'regulatory focus theory', it was hypothesized that when employees perceive their performance management system to be consistent, they develop positive outcome expectations, which primes their achievement-oriented motivation (promotion regulatory focus) and increases their engagement. Responses were collected from 779 employees belonging to three large, multi-national organizations in India. Data were analyzed using PLS-SEM package ADANCO and Hayes' PROCESS macro. Support was found for a moderated-mediation model. Specifically, promotion focus was found to mediate the relationship between performance management system consistency and work engagement, while positive affect moderated the relationship between performance management system consistency and promotion focus. The study advances scholarly understanding of the psychological impact of performance management systems on employees by clarifying the cognitive-affective processes underlying this relationship. The study also adds to the literature on work engagement by establishing consistency as a key attribute for performance management systems to act as a 'job resource' for employees and enhance their engagement. The study makes a strong case for organizations to look at performance management as an integrated system and move away from an insular focus on performance-related practices such as appraisals.
\end{abstract}

\title{
KEYWORDS
}

Performance Management System, HRM Consistency, Work Engagement, Regulatory Focus, Affect

\section{INTRODUCTION}

Work engagement has attracted considerable attention from researchers in the last decade. Studies show that engaged employees are a key source of competitive advantage (Albrecht, Bakker, Gruman, Macey, \& Saks, 2015; Bakker \& Albrecht, 2018; Bedarkar \& Pandita, 2014) and have a substantial impact on organizational performance (Harter, Schmidt, \& Hayes, 2002; Kim, Kolb, \& Kim, 2013; Schneider, Yost, Kropp, Kind, \& Lam, 2018). While monitoring employee engagement levels has become an industry norm, continually engaging employees remains a challenge for most organizations. A report by the global consulting firm Gallup corporation estimates that less than thirty percent employees feel engaged in their job (Mann \& Harter, 2016).

In this context, scholarly attention has shifted to the role of internal HR systems and processes that promote engagement, especially the role of the employee performance management system (Albrecht et al., 2015). The mandate of a performance management system in an organization is to facilitate employee efforts in meeting the organization's performance expectations (DeNisi, 2011).

\footnotetext{
a Indian Institute of Management, Nagpur

$\mathrm{b}$ Indian Institute of Management, Ahmedabad

Corresponding Author:

Kakkar (shiva@iimnagpur.ac.in)
} 
Nevertheless, performance management has been seen as both, a 'job resource' through which organizations provide support to employees (in the form of planning, coaching, evaluation and recognition of efforts) (Gruman \& Saks, 2011) as well as a 'job demand', owing to the organizational tendency to use performance management as a disciplinary system to control employee behavior (Tweedie, Wild, Rhodes, \& Martinov-Bennie, 2019). Some scholars suggest that (dis)engagement is a form of employee reciprocation to performance management, based on how they perceive the system (Bradler, Dur, Neckermann, \& Non, 2016; Pichler, 2012).

Prior studies have examined how perceptions of performance appraisal relate to engagement (refer, Cravens, Oliver, Oishi, \& Stewart, 2015; Gupta \& Kumar, 2012; Kampkötter, 2017). However, there is a growing realization that looking at performance appraisals alone is insufficient since appraisal is a backward-looking activity that only measures past performance (Armstrong, 2009). The actual development of performance is contingent upon how appraisal is used to make changes to the goalsetting, feedback, and reward processes to help employees improve (Audenaert, Decramer, George, Verschuere, \& Van Waeyenberg, 2019; DeNisi \& Murphy, 2017). Thus, employee performance development calls for close alignment and complementarity between various types of practices (Han, Kang, Oh, Kehoe, \& Lepak, 2018). This alignment has been termed as 'performance management system consistency'.

While consistency has been shown to positively influence engagement in a number of other HR system configurations (Ananthram, Xerri Matthew, Teo Stephen, \& Connell, 2018; Chen, Uen, \& Chen, 2016; Li, Sanders, \& Frenkel, 2012), no studies have examined the relationship between performance management system consistency and work engagement. HR systems cause changes in employees' proximal mental states that lead to engagement (Boxall, Ang, \& Bartram, 2011; Neubert, Kacmar, Carlson, Chonko, \& Roberts, 2008). Very little is known about these proximal psychological mechanisms, with some authors terming this gap as the 'black-box' of HR systems research (Messersmith, Patel, Lepak, \& Gould-Williams, 2011). The present study tries to address this issue using the 'regulatory focus theory' (RFT). The regulatory focus theory (RFT) (Higgins, 1998) explains the relationship between goals and individual motivation for goal pursuit. It postulates that when individuals expect that goal pursual will result in positive payoffs, they are motivated to strive harder and approach challenges (Freitas, Liberman, Salovey, \& Higgins, 2002). Based on the RFT, it is argued that consistent performance management systems enhance goal clarity and elicit expectations of positive organizational outcomes that make employees more promotion-focused. Enhanced promotion focus enables employees to direct their energies towards organizational (and personal) goals with increased vigor, dedication and absorption, resulting in greater engagement (Schaufeli, Salanova, González-Romá, \& Bakker, 2002). Thus, promotion focus is hypothesized to mediate the relationship between performance management system consistency and work engagement.

Prior work on regulatory focus shows that affect plays an important role in determining promotion focus activation (Baas, De Dreu, \& Nijstad, 2011). Positive affect broadens the perceptual focus of individuals, making them more attentive towards the modalities of workplace systems and events (Fredrickson, 2004). Termed as the 'broaden-and-build' model of affect, the theory suggests that positive emotional experiences foster greater exploration and inquisitiveness in individuals, which enhances their motivation to approach workplace challenges (Fredrickson \& Branigan, 2005). Based on this, it is hypothesized that positive affect would moderate the mediating relationship between performance management system consistency and engagement, such that those showing high positive affect will experience stronger promotion focus activation and experience higher engagement.

This study makes several significant contributions. In the recent past, there has been much debate regarding the utility of performance management systems. Some scholars view performance management as a developmental intervention to foster productive behaviors (Lee, Idris, \& Tuckey, 
2019; West \& Kelly, 2018), while others view it as an instrument for exerting greater management control (Tweedie et al., 2019). The study provides a more nuanced understanding of this issue by highlighting how consistency can ultimately determine whether employees perceive the system to be developmental or control-oriented. While prior studies have looked at how individual practices of performance management (such as, appraisal or feedback) affect employee behavior (refer, Gupta \& Kumar, 2012; Stokes, Jessica Wells, Ann Rowland, \& David Hall, 2013; Volpone, Avery, \& McKay, 2012), the focus of this study is on the 'linkages' between performance management practices. In doing so, this work contributes to the growing literature on HRM consistency and adds support to the scholarly position that complementarity between HR practices plays a critical role in determining employee behavior (Audenaert et al., 2019; Chen et al., 2016; Fu, Flood, Rousseau, \& Morris, 2018; Sanders \& Yang, 2016). The study also contributes to the work engagement literature by identifying performance management system consistency as an antecedent and brings more clarity to the performance management-work engagement relationship. Lastly, the study sheds light on the cognitive impact of performance management systems on employees by introducing the 'regulatory focus theory' and 'broaden-and build theory' to HR systems literature. This helps advance scholarly understanding regarding the motivational effects of HR systems and can aid organizations in designing systems that are more employee-friendly and development-oriented (Ferreira \& Otley, 2009).

\section{LITERATURE REVIEW}

\section{PERFORMANCE MANAGEMENT SYSTEM CONSISTENCY}

Performance management system consistency refers to the inter-relatedness of practices of goalsetting, feedback, appraisal, and rewards working together to develop employee performance (Bernthal, 1996). The term 'performance management' is often used interchangeably with 'performance appraisal', although the two have different objectives (DeNisi \& Murphy, 2017). The objective of performance appraisal is to 'measure past performance' by assigning a quantitative score to help managers identify competency gaps and distribute rewards (DeNisi \& Sonesh, 2011). The objective of performance management on the other hand, is to 'develop future performance' by changing employee behavior (DeNisi and Sonesh, 2011). According to Armstrong (2009), appraisal (rating) serves as an 'input' based on which other practices are adjusted to create behavioral changes necessary to improve performance. Thus, developing performance is not the outcome of a single practice but requires close co-ordination between various practices. This interdependence between various (performance management) practices is termed as 'consistency' (Han et al., 2018). A performance management system is deemed to be consistent when - i) personal goals are clearly connected to organizational goals, ii) the feedback provided is in line with the goals set, iii) the appraisal accurately reflects the feedback provided, and iv) the rewards are commensurate with the appraisal performed (Sharma, Sharma, \& Agarwal, 2016).

Inconsistency between performance management practices can undermine employee trust in the system (Piening, Baluch, \& Ridder, 2014). For example, studies have noted that managers often give lenient feedback to maintain social desirability among subordinates (McFarland \& Miller, 1994; Rosen, Levy, \& Hall, 2006). However, the same leniency may not be reflected in the appraisal process, where managerial scrutiny is more stringent (Wilson, 2010). As a result, appraisal ratings often tend to diverge from the feedback given by the manager. This inconsistency between appraisal and feedback leads to a breach of employee trust in the organization. As a result, employees become reluctant to accept the feedback provided and resist making changes to their behavior, leading to low performance (Piening et al., 2014). 
A recent study by Audenaert et al. (2019) found performance management consistency to be positively related to innovation performance in employees. Chen et al. (2016) found that HR consistency positively influenced job performance as well as perceptions of justice among employees. Sanders, Yang, and Li (2017) found that HR consistency positively influenced affective commitment and innovative behavior of employees. Chacko and Conway (2019) found that consistent HRM systems enhanced positive affect and work engagement of employees. Li et al. (2012) also found HRM consistency to be positively associated with work engagement.

\section{WORK ENGAGEMENT}

Work engagement is defined as a "positive, fulfilling, work-related state of mind characterized by vigor, dedication, and absorption" (Schaufeli, Salanova, González-Romá, and Bakker, 2002, p. 702). Engagement is a precursor to multiple performance dimensions, including task (Sekhar, Patwardhan, \& Vyas, 2018), contextual (Christian, Garza, \& Slaughter, 2011), adaptive (Kaya \& Karatepe, 2020), and organizational performance (Pombo \& Gomes, 2018). Engaged employees exhibit high job satisfaction (Rayton and Yalabik, 2014), commitment (Agyemang \& Ofei, 2013) and reduced turnover intentions (Bhatnagar, 2012). Studies show that engaged employees attribute work outcomes to their decisions and actions, rather than the organization, and thereby maintain a strong sense of autonomy and agency over their work (Orth \& Volmer, 2017). This in fact, has led researchers to suggest that rather than managing performance directly, organizations should use performance management systems to manage employee engagement as an indirect way to enhance performance (Gruman \& Saks, 2011; Noronha, Aquinas, \& Manezes, 2018).

A framework helpful in understanding the relationship between HR systems and engagement is the 'Job demands - resources' theory (JD-R) model (Bakker, Demerouti, \& Sanz-Vergel, 2014). 'Job demands' are aspects of the work environment that put physical, cognitive, or emotional costs on employees. In contrast, 'job resources' are the physical, social, or organizational characteristics that help employees alleviate these demands (Bakker et al., 2014). Bakker et al. (2014) postulate that in order to be engaged, employees need to have both job demands and resources, but the number of job resources must exceed the demands. Performance management plays a vital role in achieving this job demands - resources balance. By setting goals and assessment criteria, the performance management system creates job demands for employees. Simultaneously, by providing feedback and rewards, the system guides employees to enhance performance and informs them about the payoffs associated with it, thus creating essential job resources that cater to the job demands (Gruman and Saks, 2011).

When a performance management system is inconsistent, such that the feedback provided is not aligned with the goals set; or, the appraisal ratings do not match the feedback provided, employees get a confusing picture of the organization's performance expectations and become unsure about the payoffs of such work (Biron, Farndale, \& Paauwe, 2011). Such a system is able to create requisite job demands but fails to create the job resources necessary for coping with the demands, leading to loss of engagement. Conversely, a consistent performance management system is able to better demonstrate how the organization plans to support, assess and reward employee efforts as its practices are tightly interlinked (Van Waeyenberg \& Decramer, 2018). It is argued that this enables the system to create more job resources than demands, which results into increased engagement.

Studies show that factors detrimental to performance management system consistency, such as goal ambiguity (Andrews \& Mostafa, 2019), poor feedback (Borden, Levy, \& Silverman, 2018) and lack of appraisal fairness (Stokes et al., 2013) reduce engagement, whereas factors that improve system consistency, such as goal clarity (Shrivastava and Purang, 2011), constructive feedback (Dasborough 
et al., 2011; Lee et al., 2019) and appraisal quality (Gupta \& Kumar, 2012; Hoole \& Hotz, 2016; Karatepe, 2011) increase engagement. Therefore, it is hypothesized that,

Hypothesis 1: Performance management system consistency is positively related to work engagement.

\section{MEDIATING ROLE OF PROMOTION REGULATORY FOCUS}

Engagement has been described as a growth-oriented mindset demonstrated by a motivation to strive for accomplishment (Keating \& Heslin, 2015). Engaged employees continuously scout the environment for developmental opportunities, and are challenge oriented (Keating and Heslin, 2015). The 'Regulatory focus theory' (RFT) attributes the motivation to strive for accomplishment to the cognitive mechanism of promotion focus and the motivation to avoid situations to prevention focus (Higgins, 1998). Collectively, these two mechanisms together are termed as 'regulatory focus'. Expectation of positive (or negative) outcomes activates the corresponding regulatory subsystem of promotion (or prevention) focus, respectively (Higgins, 1998). Promotion focus creates an urge in employees to fulfill their growth-related needs, thereby making them more risk-oriented, perseverant, and enthusiastic (and vice-versa) (Higgins, 1998).

Consistency can have a substantial impact on outcome expectations (Van De Voorde \& Beijer, 2015). For instance, inconsistent performance management practices, such as goal ambiguity, imprecise feedback, or poor appraisal practices, create uncertainty in employees regarding the direction and quality of their efforts (Lucas, Knoben, \& Meeus, 2018; Song, Meier, \& Amirkhanyan, 2020). Inconsistency also creates doubts on how the organization intends to support, assess, and recognize employee efforts (Sharma et al., 2016). This in turn, negates the development of positive outcome expectations, as employees fail to see how adherence to the performance management process effectively contributes to their growth and development within the organization.

Conversely, since consistent systems can better communicate how the organization intends to support employee efforts, they develop positive outcome expectations (Chacko \& Conway, 2019; Van De Voorde \& Beijer, 2015). It is argued that positive outcome expectations activate the employees' promotion regulatory focus, as they perceive that adhering to the performance management system will lead to growth and accomplishment in the future. This makes employees more willing to accept feedback and make efforts to improve their performance, which increases their engagement.

Prior studies show that outcome expectations set by other organizational factors (such as supervisors) tend to influence employee regulatory focus. Johnson et al. (2017) found that outcome expectations set by leaders influenced subordinate regulatory focus activation. Transformational leaders are known to elicit promotion focus in subordinates by setting inspirational goals (Henker, Sonnentag, \& Unger, 2015; Lai, Hsu, \& Li, 2018). There is also evidence that promotion focus is positively related to engagement (Andrews, Kacmar, \& Valle, 2016; Lanaj, Chang, \& Johnson, 2012). Based on this, it is hypothesized that,

Hypothesis 2: Promotion focus will mediate the relationship between performance management system consistency and work engagement.

\section{MODERATING ROLE OF POSITIVE AFFECT}

Positive affect is the tendency to be cheerful, energetic, and experience positive moods and emotions across different situations (Barsade \& Gibson, 2007). Research suggests that positive affect can interact with the approach-avoidance motivational subsystem to influence evaluation and reaction to 
workplace situations (Tugade \& Fredrickson, 2007). In the 'Broaden-and-build' theory of emotions, Fredrickson (2001) proposed that positive affect 'broadens' the cognitive and perceptual focus of individuals, facilitating the reception and integration of information from diverse sources. This enables individuals to see the 'larger picture' by establishing connections between different aspects of (workplace) events. Effectively, the experience of this larger picture 'builds' psychological, social, and intellectual resources that increase the individual's self-competence and develops a positive and optimistic outlook towards work, making it seem more meaningful (Fredrickson \& Branigan, 2005).

Based on this, it can be implied that individuals with high positive affect are likely to develop stronger perceptions of performance management consistency since they can recognize the interconnections between various performance management practices and how these contribute to their work. Recent studies show that positive affect enhances employee perception and develops more favorable evaluations of HR systems (Chacko and Conway, 2019). Moreover, since positive affect accentuates (positive) outcome expectations (which in turn leads to promotion focus activation), it is reasonable to suggest that positive affect further bolsters promotion focus activation (refer, Figure 1). Studies in the creativity domain have found that positive affect strengthens promotion focus activation in employees and increases creative and innovative behaviors (de Buisonjé, Ritter, de Bruin, ter Horst, \& Meeldijk, 2017; Yeh, Lai, \& Lin, 2016). Based on this, it is hypothesized that,

Hypothesis 3: Positive affect moderates the relationship between performance management system consistency and promotion focus, such that the positive relationship between performance management system consistency and promotion focus is stronger for individuals with high positive affect than those with low positive affect.

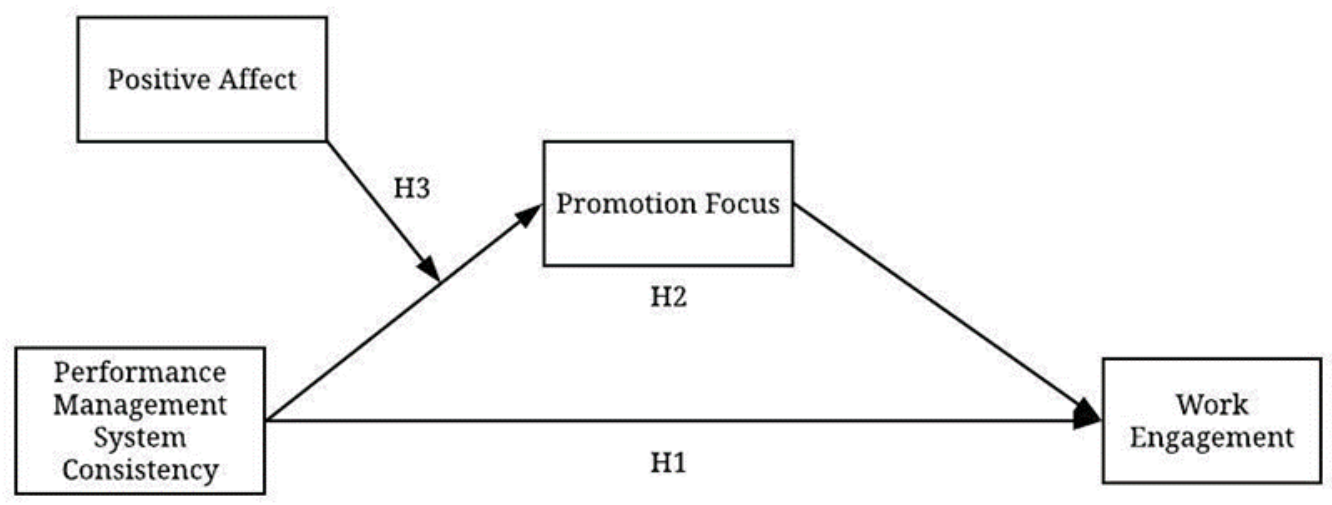

Figure 1. Hypothesized Model

\section{METHODOLOGY}

\section{SAMPLE}

The sample consisted of executives and managers knowing English with a minimum of 2 years of work experience to ensure adequate exposure to the organization's performance management system. Data were collected from three large multinational organizations and their subsidiaries belonging to the steel, media, and hospitality sectors in India. Data collection was done online in co-ordination with the HR departments of the respective organizations. E-mail invitations were sent to participants with a cover letter briefly explaining the study's purpose, with a hyperlink to the survey page. A 'force response' validation was added to the survey to ensure that respondents answered all questions and no questions were skipped. The survey was sent out to a total of 1686 participants, out of which 848 
responses were received. The response rate was 50.30\%. During the data sufficiency check, 69 responses were deleted based on incomplete surveys or ineligibility of respondents on account of the work experience criteria. The final data set consisted of 779 responses (see Table 1).

Table 1. Sample Description

\begin{tabular}{clc}
\hline & \multicolumn{1}{c}{$\mathbf{n}$} & $\%$ \\
\hline Gender & 779 & \\
Male & 730 & 93.71 \\
Female & 49 & 6.29 \\
Age mean & 37.5 years & \\
$<30$ & 144 & 18.49 \\
30-40 & 341 & 43.77 \\
40-50 & 201 & 25.80 \\
$>$ 50 & 93 & 11.94 \\
Work Experience & 8.8 years & \\
2-5 years & 276 & 35.43 \\
5-8 years & 165 & 21.18 \\
8-12 years & 154 & 19.77 \\
$>$ 12 years & 184 & 23.62 \\
\hline
\end{tabular}

\section{MEASURES}

Responses were collected on a 7-point Likert scale ranging from 'strongly disagree' to 'strongly agree.' Standardized instruments were used to measure the relevant variables. Reliability of the instruments was assessed using Cronbach $a$. A Cronbach a value of $>0.70$ is required to establish construct reliability (Hair, Black, Babin, Anderson, \& Tatham, 2006). As shown below, values for all constructs were above 0.80 .

Table 2. Measurement Model Results

\begin{tabular}{clcc}
\hline Construct & Cronbach a & AVE & VIF \\
\hline $\begin{array}{c}\text { Performance Management } \\
\text { System Consistency }\end{array}$ & 0.94 & 0.60 & 2.23 \\
Promotion Focus & 0.83 & 0.52 & 1.27 \\
Work Engagement & 0.86 & 0.53 & 1.50 \\
Positive Affect & 0.90 & 0.72 & 2.17 \\
\hline
\end{tabular}

Convergent and discriminant validity of the constructs was assessed using AVE (average variance extracted) and HTMT (Heterotrait - monotrait ratio of correlations), respectively (Henseler, Hubona, 
\& Ray, 2016). Convergent validity is established for AVE > 0.5 (Hair et al., 2006) (refer, Table 2). Discriminant validity is established for HTMT < 0.9 (Henseler et al., 2016). The discriminant validity scores along with construct correlations are shown in Table 3. Details of the survey instruments used are as follows:

Performance management system consistency was measured using the 12-item instrument developed by Sharma et al. (2016). A few sample items are "My manager and I update my goals frequently as business goals change" and "Annual feedback during performance review is an accurate representation of the ongoing feedback during the performance cycle."

Work engagement was measured using the 9-item 'Utrecht Work Engagement Scale' (UWES-9) devised by (Schaufeli, Bakker, \& Salanova, 2006). Sample items include "At my job, I feel strong and vigorous" and "I get carried away when I am working". One item ("When I get up in the morning, I feel like going to work") was dropped due to poor loading ( $<0.5)$.

Promotion focus was measured using the 9 -item scale developed by Neubert et al. (2008). Sample items are "I take chances at work to maximize my goals for advancement" and "If I had an opportunity to participate in a high-risk, high-reward project, I would definitely take it." Two items ("I focus on accomplishing tasks that will further my advancement" and "My work priorities are impacted by a clear picture of what I aspire to be") were dropped due to low factor loadings ( $<0.5)$.

Positive affect was measured by adapting items from the positive and negative affect scale (PANAS) developed by Thompson (2007). The participants were asked to respond to the statement, "At my workplace, I generally feel," - on the five positive affect dimensions.

Table 3. Correlations and Discriminant Validity Results

\begin{tabular}{|c|c|c|c|c|c|c|}
\hline Construct & $\mathbf{M}$ & SD & $\begin{array}{c}\text { Performance } \\
\text { Management } \\
\text { System } \\
\text { Consistency }\end{array}$ & $\begin{array}{l}\text { Promotion } \\
\text { Focus }\end{array}$ & $\begin{array}{c}\text { Work } \\
\text { Engagement }\end{array}$ & $\begin{array}{c}\text { Positive } \\
\text { Affect }\end{array}$ \\
\hline $\begin{array}{l}\text { Performance management } \\
\text { system consistency }\end{array}$ & 4.90 & 1.20 & 1 & $(0.44)$ & $(0.55)$ & $(0.78)$ \\
\hline Promotion Focus & 5.58 & 0.88 & $0.38 * *$ & 1 & $(0.54)$ & $(0.44)$ \\
\hline Work Engagement & 5.66 & 0.96 & $0.49^{* *}$ & $0.46^{* *}$ & 1 & $(0.57)$ \\
\hline Positive Affect & 5.61 & 1.31 & $0.71 * *$ & $0.38 * *$ & $.51^{* *}$ & 1 \\
\hline
\end{tabular}

Note. ** Correlation is significant at 0.01 level (two tailed). Correlation constructs are below the diagonal elements. HTMT values in parentheses.

\section{CONTROLS}

Gender, age, and work experience were used as control variables. Studies show that as age increases, the willingness to take risks and pursue growth opportunities decreases (Stewart \& Roth, 2001). Regulatory focus priming has also been shown to differ between age groups (Lockwood, Chasteen, \& Wong, 2005). Hence, to avoid the possibility of attributing regulatory focus orientation to the age of participants, the variable was controlled.

Studies show that as the duration of experience in an organization increases, employees develop deeper emotional bonds with it, which may reflect in the form of increased organizational commitment and engagement (Jenaro, Flores, Orgaz, \& Cruz, 2011; O'Reilly \& Chatman, 1986). To rule out the possibility that higher engagement could be on account of longer work experience, the variable was controlled. 
According to Sassenberg, Brazy, Jonas, and Shah (2013), males are perceived to be more powerdriven and competitive, which leads them to adopt promotion-focused strategies more frequently. However, some other empirical studies did not find any gender differences in regulatory focus (Lee, Aaker, \& Gardner, 2000; Llewellyn, Dolcos, Iordan, Rudolph, \& Dolcos, 2013). To prevent the possibility of the variable confounding the findings, it was decided to control for gender.

\section{DATA ANALYSIS AND RESULTS}

PLS-based structure equation modeling (SEM) package ADANCO and Hayes (2017) PROCESS macro for SPSS was used for data analysis. Data was first checked for common method variance (CMV). Several steps were taken to detect and mitigate CMV; for instance, before survey administration, face validity checks were performed to rule out any ambiguity in the survey items (Podsakoff, MacKenzie, Lee, \& Podsakoff, 2003). Items were randomized, and different labels were used for recording the responses (i.e., Very True/Untrue of me and/or, Strongly Agree/Strongly Disagree) (MacKenzie \& Podsakoff, 2012). Further, to verify that these procedures reduced CMV, Harman's single factor test was used (Hair et al., 2006). The results indicated that the single largest factor explained only $29.22 \%$ of variance (less than the suggested $50 \%$ threshold). Multicollinearity was also assessed using the variance inflation factor (VIF). A VIF value of less than 10 is acceptable, while 5 or lower is preferable (Hair et al., 2016). None of the variables exceeded the VIF cut off value of 5 , which indicated that CMV was not a significant issue (refer, Table 2).

Model testing was carried out as per the guidelines of Henseler et al. (2016). The measurement model was estimated, and then bootstrapped to check the significance of the path coefficients of the structural model. The following parameters were specified for analysis: Path-weighting scheme: Mode A, Inner weighting scheme: Factor, Maximum number of iterations $=200$, Bootstrapping samples = 5000. Hair, Sarstedt, Hopkins, and Kuppelwieser (2014) introduced SRMR as a measure for model fit for variance-based SEM techniques. A value of 1.00 is considered acceptable for model fit, while 0.08 or below is preferable (Henseler et al., 2016). The estimated structural model had an SRMR of 0.07, indicating a good model fit. The structural model results are shown in Table 4.

To test $\mathrm{H} 1$, the direct relationship between performance management system consistency and work engagement was tested. Performance management system consistency explained for $24 \%$ variance $\left(R^{2}\right)$ in work engagement. Thus, $\mathrm{H} 1$ was supported $(B=0.44, p<0.001)$ (refer, Figure 2$)$. Mediation testing was performed as per the guidelines of Nitzl, Roldan, and Cepeda (2016), which proposes that all relevant effects be tested in one single model. Promotion focus was introduced as a mediator variable between performance management system consistency and work engagement. The mediated model explained for 33\% variance in engagement, i.e., an improvement of $9 \%$ over the direct model $(\theta=0.32, p<0.001)$. Thus, $\mathrm{H} 2$ was also supported. 
Table 4. Structural Model Results

\begin{tabular}{ccccc}
\hline Relationships & SRMR & $\mathbf{R}^{2}$ & $\beta$ & Conclusion \\
\hline $\begin{array}{c}\text { H1: Performance management system } \\
\text { consistency } \rightarrow \text { Work Engagement }\end{array}$ & 0.07 & 0.24 & $0.44^{* * *}$ & Supported \\
$\begin{array}{c}\text { H2: Performance management system } \\
\text { Consistency } \rightarrow \text { Promotion Focus }\end{array}$ & 0.07 & 0.33 & $0.23^{* * *}$ & Supported \\
$\begin{array}{c}\text { Promotion Focus } \rightarrow \text { Work Engagement } \\
\text { H3: Positive Affect } \rightarrow \text { Promotion Focus }\end{array}$ & & & $0.32^{* * *}$ & \\
$\begin{array}{c}\text { Positive Affect x Performance } \\
\text { management system consistency } \rightarrow \\
\quad \text { Promotion Focus }\end{array}$ & 0.05 & 0.37 & $0.30^{* * *}$ & \\
& & & $0.12^{*}$ & Supported \\
\hline
\end{tabular}

Note. ${ }^{*} p<.05 .{ }^{* *} p<.01 .{ }^{* * *} p<.001$.

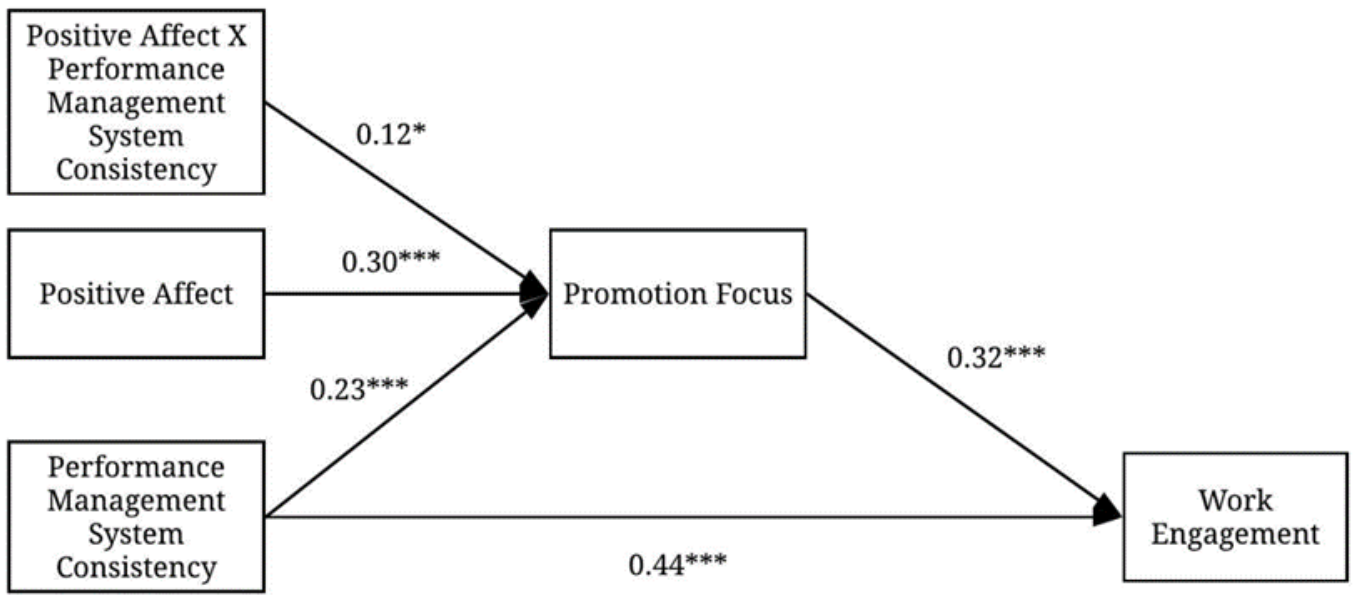

Figure 2. Structural Model with Path Coefficients

\section{TESTING FOR MODERATED MEDIATION}

Moderated mediation was tested using the PROCESS macro for SPSS. The latent variable scores calculated in ADANCO were used as input for PROCESS (Model 7). Bootstrapping was set to 10000 samples. Moderated mediation is said to exist when the bootstrap confidence interval of the index of moderated mediation does not contain zero (Hayes, 2017). The index was 0.03 , and the bootstrap $\mathrm{Cl}$ did not contain zero, indicating moderated mediation thereof. Thus, $\mathrm{H} 3$ was also supported (see Table 5).

The final model explained for $37 \%$ variance in work engagement, i.e., an improvement of $13 \%$ over the direct model (see Table 5). The conditional indirect effects of the moderator were assessed at high and low values of the moderator variable ( $+/-1$ standard deviation from the mean). Results showed that the indirect effect of performance management system consistency on work engagement through promotion focus was stronger for employees with high positive affect $\left(\beta=0.13, \mathrm{SE}_{\mathrm{Boot}}=0.02\right.$, $95 \% \mathrm{Cl}=0.08$ to 0.18$)$ than for employees with low positive affect $\left(\beta=0.07, \mathrm{SE}_{\mathrm{Boot}}=0.02,95 \% \mathrm{Cl}=0.03\right.$ to 0.12) (refer Table 5). 


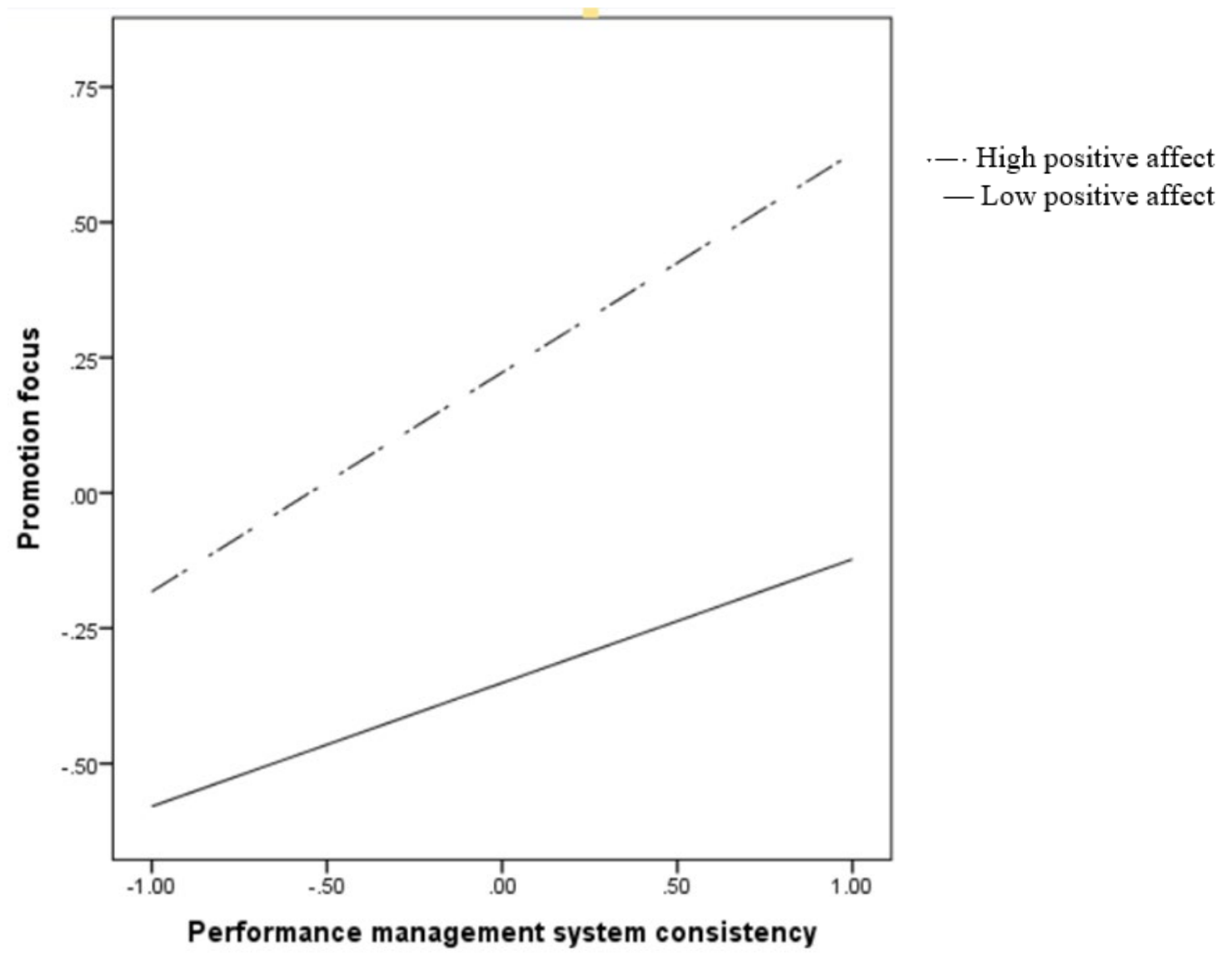

Figure 3. Plot for Moderated Mediation 
Table 5. Results for Moderated Mediation

\begin{tabular}{|c|c|c|c|c|}
\hline \multirow[b]{2}{*}{ IV } & \multicolumn{2}{|c|}{$\begin{array}{c}\text { Mediator } \\
\text { Promotion Focus }\end{array}$} & \multicolumn{2}{|c|}{$\begin{array}{c}\text { DV } \\
\text { Work Engagement }\end{array}$} \\
\hline & B & $S E_{B}$ & B & $S E_{B}$ \\
\hline Gender & -.04 & .03 & -.01 & .03 \\
\hline Age & -.09 & .04 & .04 & .03 \\
\hline Current Work Experience & .01 & .04 & .01 & .03 \\
\hline $\begin{array}{l}\text { Performance Management System } \\
\text { Consistency }\end{array}$ & $.30^{*}$ & .04 & $.40^{*}$ & .03 \\
\hline Positive Affect & $.28^{*}$ & .05 & - & - \\
\hline $\begin{array}{l}\text { Performance Management System } \\
\text { Consistency X Positive Affect }\end{array}$ & $.08^{*}$ & .02 & - & - \\
\hline Promotion Focus & - & - & $.32 *$ & .03 \\
\hline Direct, Indirect and Total Effects & Effect & $S E_{B}$ & LL & $U L$ \\
\hline Direct Effect & $.37^{*}$ & .03 & {$[.31$} & $.44]$ \\
\hline \multicolumn{5}{|l|}{$\begin{array}{l}\text { Conditional Indirect Effect of } \\
\text { Moderator }\end{array}$} \\
\hline Low Positive Affect (-1SD) & $.07^{*}$ & .02 & {$[.03$} & $.12]$ \\
\hline High Positive Affect (+1SD) & $.13^{*}$ & .02 & {$[.08$} & $.18]$ \\
\hline Index of Moderated Mediation & Index & $S E_{B}$ & LL & $U L$ \\
\hline Promotion Focus & .03 & .01 & {$[.003$} & $.05]$ \\
\hline
\end{tabular}

Note. ${ }^{*} \mathrm{p}<.05$

\section{DISCUSSION}

Gruman and Saks (2011) postulate that well designed performance management systems could play a critical role in driving employee engagement. However, what characteristics of performance management systems contribute to a 'good' system design is rather unclear. The results of this study provide empirical support to Gruman and Saks' position and add to it by identifying 'consistency' as a key boundary condition for performance management systems to drive engagement $(\mathrm{H} 1)$. The results are in-line with prior studies that have found consistency in other HR systems to be a precursor to engagement (Guan \& Frenkel, 2018; Li et al., 2012).

The focus on performance management system consistency has gained scholarly attention fairly recently. The sole article published in a top-tier journal exploring the issue is by Audenaert et al. (2019), who looked at the relationship between performance management system consistency and innovation in a sample of Dutch, non-profit workers. Engagement is a well-established antecedent of innovative behaviors (Kwon \& Kim, 2020). From this, it can be inferred that the relationship between performance management system consistency and positive employee attitudes (such as engagement) is fairly consistent across different cultural contexts. 
Promotion focus was found to mediate the relationship between performance management system consistency and work engagement $\left(\mathrm{H}_{2}\right)$. Prior studies have examined the influence of supervisors (Henker et al., 2015; Lai et al., 2018), team processes (Shin, Kim, Choi, \& Lee, 2015), and work characteristics (Lanaj et al., 2012) on employee regulatory focus, but have largely ignored organizational systems. This study shows that outcome expectations formed by consistent performance management can influence the regulatory focus of employees, and affect their work outcomes. The study also lends support to emerging theoretical work in the field which suggests that organizational practices can influence regulatory focus orientation among employees and their cognitive implications should be accounted for during system design (Bozer \& Delegach, 2019).

Positive affect was found to moderate the relationship between performance management system consistency and promotion focus activation ( $\left.\mathrm{H}_{3}\right)$. Figure 3 shows that individuals with high positive affect have stronger perceptions of consistency. This can be understood using the 'affect-asinformation' model, which posits that individuals use affective cues from the general environment (in this case, the workplace) to make judgments about specific events or artifacts of the environment (Zadra \& Clore, 2011). The plot also indicates that promotion focus activation is more potent for high positive affect employees. This suggests that happier employees tend to pick up consistency related cues faster, and are more likely to make changes to their behavior. Further, this also supports the position taken by a growing number of studies, which suggest that organizations need to focus on the employees' emotional experience of HR systems and of the organization in itself, as this may effectively determine their willingness and frequency of using these systems (Woodrow \& Guest, 2014).

\section{THEORETICAL CONTRIBUTION}

The first contribution of this study is to the performance management literature. HRM scholars have long debated the utility and effectiveness of performance management in engaging employees (Tweedie et al., 2019). While strategic HRM researchers view performance management system as an indispensable asset in managing employee motivation (refer, DeNisi \& Murphy, 2017; Han et al., 2018; Pulakos, Mueller-Hanson, \& Arad, 2019), critical HRM theorists view it as a control mechanism that limits employee autonomy and thwarts engagement (Das, 2018; Tweedie et al., 2019). This study supports the position of strategic HRM scholars by presenting evidence that performance management influences employee attitudes positively, provided it is a consistent system. Consistent systems can clarify the link between personal-organizational goals better, which cognitively primes employees for achievement and makes them more engaged.

The second contribution is to the work engagement literature. Theoretical work suggests that performance management can influence engagement when experienced as a psychological resource (Guan \& Frenkel, 2018; Noronha et al., 2018). This study identifies 'consistency' as one of the boundary conditions to be fulfilled for performance management to function as a job resource. The study also brings more clarity to the relationship between performance management and work engagement. Prior studies have used appraisal as a proxy for performance management, and have not taken a system-based approach that focuses on interlinkages (refer, Gupta \& Kumar, 2012; Poon, 2004; Stokes et al., 2013). Studies have ignored the fact that the collective impact of a system is different than its isolated practices (Han et al., 2018). This work overcomes these limitations and adds performance management system consistency as an antecedent of work engagement.

The psychological impact of HR systems (including that of performance management) on employees has been poorly understood until now. Many researchers have termed this relationship as the 'black-box' of HRM (Boxall et al., 2011, Messersmith et al., 2011). The third contribution of this study 
lies in uncovering the inner mechanics of this 'black-box' by identifying promotion focus as a mediating mechanism between performance management system consistency and work engagement.

Lastly, the study contributes to the research on affect, specifically to the 'broaden-and-build' theory. Although the theory proposes engagement to be an outcome of positive affect, the relationship is not empirically well established (Vacharkulksemsuk \& Fredrickson, 2013). This study shows that positive affect indirectly fosters engagement by strengthening promotion focus activation. The findings also lend support to emerging studies that propose that workplace affect can determine the effectiveness of HR systems in shaping employee attitudes and behaviors (Alfes et al., 2019; Chacko \& Conway, 2019).

\section{MANAGERIAL CONTRIBUTION}

The study makes a strong case for organizations to put greater focus on performance management system consistency. The role of the line manager may be crucial in this regard. The way managers execute performance management practices can determine employee experience of consistency (Fu et al., 2018). To prevent instances of managerial failure to align performance management practices with each other, organizations need to change their approach towards performance management. This includes communicating the broader motivational goals of performance management to managers, and refraining from over-emphasizing quantitative practices like appraisal (Shrivastava \& Rajesh, 2017).

The positive relationship between performance management system consistency and promotion focus also highlights the importance of 'message framing'. Message framing refers to the way in which information, actions, or decisions are emphasized in communication, leading to a change in the regulatory focus of the listener, thereby influencing his/her behavior (Rhee \& Fiss, 2014). In workplace contexts, framing can be used to create better alignment between performance management practices and make them more development-oriented. For example, the activity of 'appraisal review' can be reframed positively as 'performance discussion' focusing not just on evaluating past performance but also on exploring future aspirations of employees. This can help diffuse the stress associated with appraisals, create positive expectations (Buckingham \& Goodall, 2015) and help prime employee promotion focus. Thus, organizations do need to take cognizance of what sort of 'message' the system is giving to employees in order to stimulate their motivation and engagement (Nishii, Lepak, \& Schneider, 2008).

Consistency can also be achieved through structural changes such as the use of 'Employee Development Agreements' (EDA's) and methodologies like 'Objectives and Key Results' (OKR). Under EDA's, employees self-enlist short to medium-term developmental goals, and the support required from the organization to meet these goals (Buckingham \& Goodall, 2015). By making tacit expectations salient, EDAs signal to employees that the organization supports their career aspirations and trusts their ability to manage their performance (Church \& Rotolo, 2016). OKR is an innovative goal-setting methodology that focuses on autonomous goal-setting, continuous feedback, and assessment through technology (Doerr, 2018). Industry experts increasingly view OKR as a performance management method owing to its strong emphasis on bringing consistency both vertically (i.e., between individual, team, departmental, and organizational level objectives) as well as horizontally (between performance management practices) (West \& Kelly, 2018).

\section{LIMITATIONS AND FUTURE RESEARCH}

This study has some limitations. First, although theory supports performance management as a driver of engagement, the cross-sectional design of the study does not allow for determination of causality 
between variables. Second, the use of self-report data from a single source does leave concerns regarding $C M V$. While several precautionary measures were taken to address $C M V$, the problem could have been better addressed using more recent methods such as the marker variable technique (Fuller, Simmering, Atinc, Atinc, \& Babin, 2016). However, this required introducing a new set of questions in the survey, which time and logistic constraints did not permit.

Future researchers can examine how factors related to implementation and execution of performance management systems, such as relationship with supervisor (LMX), organizational communication, culture and information and technology systems affect employee perceptions of consistency. Researchers can also look at how other HRM bundles (such as learning and development, diversity management, etc.) interact with performance management to affect employee experience of consistency. Researchers can replicate the study in other sectors such as the public sector, information technology sector to enhance the generalizability of the findings. An interesting issue that needs to be investigated is the construct of regulatory fit (Higgins, 2005). Studies suggest that maximum hedonic value is derived when there is a regulatory fit between the chronic and situationally induced regulatory focus of individuals (Ahmadi, Khanagha, Berchicci, \& Jansen, 2017; Cesario, Higgins, \& Scholer, 2008). Researchers can study effects of the fit between chronic and situated regulatory focus in the workplace on employee engagement, performance and wellbeing.

\section{CONCLUSION}

The objective of this study was to investigate the relationship between performance management systems and work engagement. The findings show that in addition to expected attributes of appraisal fairness and transparency, organizations need to focus on consistency of performance management systems to engage employees effectively. The study also provides insights on how consistent systems psychologically impact employees by using regulatory focus as a linking mechanism. It is hoped that this study's findings will encourage researchers (and practitioners) to pay attention to the employee experience of organizational systems and facilitate the creation of more commitment-oriented performance management systems. 


\section{REFERENCES}

Agyemang, C. B., \& Ofei, S. B. (2013). Employee work engagement and organizational commitment: A comparative study of private and public sector organizations in Ghana. European Journal of Business and Innovation Research, 1(4), 20-33.

Ahmadi, S., Khanagha, S., Berchicci, L., \& Jansen, J. J. (2017). Are managers motivated to explore in the face of a new technological change? The role of regulatory focus, fit, and complexity of decision-making. Journal of Management Studies, 54(2), 209-237.

Albrecht, S. L., Bakker, A. B., Gruman, J. A., Macey, W. H., \& Saks, A. M. (2015). Employee engagement, human resource management practices and competitive advantage: An integrated approach. Journal of Organizational Effectiveness: People and Performance, 2(1), 7-35.

Alfes, K., Shantz, A. D., Bailey, C., Conway, E., Monks, K., \& Fu, N. (2019). Perceived human resource system strength and employee reactions toward change: Revisiting human resource's remit as change agent. Human Resource Management, 58(3), 239-252.

Ananthram, S., Xerri Matthew, J., Teo Stephen, T. T., \& Connell, J. (2018). High-performance work systems and employee outcomes in Indian call centres: a mediation approach. Personnel Review, 47(4), 931-950.

Andrews, M. C., Kacmar, K. M., \& Valle, M. (2016). Surface acting as a mediator between personality and attitudes. Journal of Managerial Psychology, 31(8), 1265-1279.

Andrews, R., \& Mostafa, A. M. S. (2019). Organizational goal ambiguity and senior public managers' engagement: does organizational social capital make a difference? International Review of Administrative Sciences, 85(2), 377-395.

Armstrong, M. (2009). Armstrong's handbook of performance management: An evidence-based guide to delivering high performance. Philadelphia, PA: Kogan Page Publishers.

Audenaert, M., Decramer, A., George, B., Verschuere, B., \& Van Waeyenberg, T. (2019). When employee performance management affects individual innovation in public organizations: The role of consistency and LMX. The International Journal of Human Resource Management, 30(5), 815-834.

Baas, M., De Dreu, C. K., \& Nijstad, B. A. (2011). When prevention promotes creativity: The role of mood, regulatory focus, and regulatory closure. Journal of Personality and Social Psychology, 100(5), 794-809.

Bakker, A. B., \& Albrecht, S. (2018). Work engagement: current trends. Career Development International, 23(1), 4-11.

Bakker, A. B., Demerouti, E., \& Sanz-Vergel, A. I. (2014). Burnout and work engagement: The JD-R approach. Annual Review of Organizational Psychology and Organizational Behaviour, 1(1), 389411.

Barsade, S. G., \& Gibson, D. E. (2007). Why does affect matter in organizations? Academy of Management Perspectives, 21(1), 36-59.

Bedarkar, M., \& Pandita, D. (2014). A study on the drivers of employee engagement impacting employee performance. Procedia-Social and Behavioral Sciences, 133, 106-115.

Bernthal, P. R. (1996). Comparing performance management practices in the United States and Pacific Rim. In B.S. Prasad (Ed.), Advances in international comparative management, (pp. 1-30), Greenwich, CT: JAI Press.

Bhatnagar, J. (2012). Management of innovation: Role of psychological empowerment, work engagement and turnover intention in the Indian context. The International Journal of Human Resource Management, 23(5), 928-951. 
Biron, M., Farndale, E., \& Paauwe, J. (2011). Performance management effectiveness: lessons from world-leading firms. The International Journal of Human Resource Management, 22(06), 12941311.

Borden, L., Levy, P. E., \& Silverman, S. B. (2018). Leader arrogance and subordinate outcomes: The role of feedback processes. Journal of Business and Psychology, 33(3), 345-364.

Boxall, P., Ang, S. H., \& Bartram, T. (2011). Analysing the 'black box'of HRM: Uncovering HR goals, mediators, and outcomes in a standardized service environment. Journal of Management Studies, 48(7), 1504-1532.

Bozer, G., \& Delegach, M. (2019). Bringing context to workplace coaching: A theoretical framework based on uncertainty avoidance and regulatory focus. Human Resource Development Review, 18(3), 376-402.

Bradler, C., Dur, R., Neckermann, S., \& Non, A. (2016). Employee recognition and performance: A field experiment. Management Science, 62(11), 3085-3099.

Buckingham, M., \& Goodall, A. (2015). Reinventing performance management. Harvard Business Review, 93(4), 40-50.

Cesario, J., Higgins, E. T., \& Scholer, A. A. (2008). Regulatory fit and persuasion: Basic principles and remaining questions. Social and Personality Psychology Compass, 2(1), 444-463.

Chacko, S., \& Conway, N. (2019). Employee experiences of HRM through daily affective events and their effects on perceived event-signalled HRM system strength, expectancy perceptions, and daily work engagement. Human Resource Management Journal, 29(3), 433-450.

Chen, S.-Y., Uen, J. F., \& Chen, C.-C. (2016). Implementing high performance HR practices in Asia: HR practice consistency, employee roles, and performance. Asia Pacific Journal of Management, 33(4), 937-958.

Christian, M., Garza, A., \& Slaughter, J. (2011). Work engagement: A quantitative review and test of its relations with task and contextual performance. Personnel Psychology, 64(1), 89-136.

Church, A. H., \& Rotolo, C. T. (2016). Lifting the veil: What happens when you are transparent with people about their future potential? People and Strategy, 39(4), 36-40.

Cravens, K. S., Oliver, E. G., Oishi, S., \& Stewart, J. S. (2015). Workplace culture mediates performance appraisal effectiveness and employee outcomes: A study in a retail setting. Journal of Management Accounting Research, 27(2), 1-34.

Das, R. (2018). Strategic human resource management: a power based critique. Benchmarking: An International Journal, 25(4), 1213-1231.

Dasborough, M., Harvey, P., Martinko, M. J., Sue-Chan, C., Chen, Z., \& Lam, W. (2011). LMX, coaching attributions, and employee performance. Group \& Organization Management, 36(4), 466-498.

de Buisonjé, D. R., Ritter, S. M., de Bruin, S., ter Horst, J. M.-L., \& Meeldijk, A. (2017). Facilitating Creative Idea Selection: The Combined Effects of Self-Affirmation, Promotion Focus and Positive Affect. Creativity Research Journal, 29(2), 174-181.

DeNisi, A. (2011). Managing performance to change behavior. Journal of Organizational Behavior Management, 31(4), 262-276.

DeNisi, A., \& Murphy, K. (2017). Performance appraisal and performance management: 100 years of progress? Journal of Applied Psychology, 102(3), 421-433.

DeNisi, A. S., \& Sonesh, S. (2011). The appraisal and management of performance at work. In S. Zedeck (Ed.), APA Handbooks in Psychology. APA handbook of industrial and organizational psychology, Vol. 2. Selecting and developing members for the organization (pp. 255-279). Washington, DC, US: American Psychological Association.

Doerr, J. (2018). Measure What Matters: OKRs: The Simple Idea that Drives 10x Growth, London, UK: Penguin Publishers. 
Ferreira, A., \& Otley, D. (2009). The design and use of performance management systems: An extended framework for analysis. Management Accounting Research, 20(4), 263-282.

Fredrickson, B. L. (2001). The role of positive emotions in positive psychology: The broaden-and-build theory of positive emotions. American Psychologist, 56(3), 218-226.

Fredrickson, B. L. (2004). The broaden-and-build theory of positive emotions. Philosophical Transactions of the Royal Society of London Series B: Biological Sciences, 359, 1367-1378.

Fredrickson, B. L., \& Branigan, C. (2005). Positive emotions broaden the scope of attention and thought-action repertoires. Cognition \& Emotion, 19(3), 313-332.

Freitas, A. L., Liberman, N., Salovey, P., \& Higgins, E. T. (2002). When to begin? Regulatory focus and initiating goal pursuit. Personality and Social Psychology Bulletin, 28(1), 121-130.

Fu, N., Flood, P. C., Rousseau, D. M., \& Morris, T. (2018). Line Managers as Paradox Navigators in HRM Implementation: Balancing Consistency and Individual Responsiveness. Journal of Management, 46(2), 203-233.

Fuller, C. M., Simmering, M. J., Atinc, G., Atinc, Y., \& Babin, B. J. (2016). Common methods variance detection in business research. Journal of Business Research, 69(8), 3192-3198.

Gruman, J. A., \& Saks, A. M. (2011). Performance management and employee engagement. Human Resource Management Review, 21(2), 123-136.

Guan, X., \& Frenkel, S. (2018). How HR practice, work engagement and job crafting influence employee performance. Chinese Management Studies, 12, 591-607.

Gupta, V., \& Kumar, S. (2012). Impact of performance appraisal justice on employee engagement: a study of Indian professionals. Employee Relations, 35(1), 61-78.

Hair, J., Black, W., Babin, B., Anderson, R., \& Tatham, R. (2006). Multivariate data analysis. In: Upper Saddle River, NJ: Pearson Prentice Hall.

Hair, J. F. J., Sarstedt, M., Hopkins, L., \& Kuppelwieser, V. G. (2014). Partial least squares structural equation modeling (PLS-SEM) An emerging tool in business research. European Business Review, 26(2), 106-121.

Hair, J. F., Hult, G. T. M., Ringle, C., \& Sarstedt, M. (2016). A primer on partial least squares structural equation modeling (PLS-SEM): Sage Publications.

Han, J. H., Kang, S., Oh, I.-S., Kehoe, R., \& Lepak, D. (2018). The Goldilocks Effect of Strategic Human Resource Management? Optimizing the Benefits of a High Performance Work System through the Dual Alignment of Vertical and Horizontal Fit. Academy of Management Journal, 62, 1388-1412.

Harter, J., Schmidt, F., \& Hayes, T. (2002). Business-unit-level relationship between employee satisfaction, employee engagement, and business outcomes: a meta-analysis. Journal of Applied Psychology, 87(2), 268-279.

Hayes, A. F. (2017). Introduction to mediation, moderation, and conditional process analysis: A regression-based approach: Guilford publications.

Henker, N., Sonnentag, S., \& Unger, D. (2015). Transformational leadership and employee creativity: the mediating role of promotion focus and creative process engagement. Journal of Business and Psychology, 30(2), 235-247.

Henseler, J., Hubona, G., \& Ray, P. A. (2016). Using PLS path modeling in new technology research: updated guidelines. Industrial Management \& Data Systems, 116(1), 2-20.

Higgins, T. (1998). Promotion and prevention: Regulatory focus as a motivational principle. Advances in Experimental Social Psychology, 30, 1-46.

Higgins, T. (2005). Value from regulatory fit. Current Directions in Psychological Science, 14(4), 209-213.

Hoole, C., \& Hotz, G. (2016). The impact of a total reward system of work engagement. SA Journal of Industrial Psychology, 42(1), 1317-1331. 
Jenaro, C., Flores, N., Orgaz, M. B., \& Cruz, M. (2011). Vigour and dedication in nursing professionals: towards a better understanding of work engagement. Journal of Advanced Nursing, 67(4), 865875.

Johnson, R. E., King, D. D., Lin, S.-H., Scott, B. A., Jackson Walker, E. M., \& Wang, M. (2017). Regulatory focus trickle-down: How leader regulatory focus and behavior shape follower regulatory focus. Organizational Behavior and Human Decision Processes, 140, 29-45.

Kampkötter, P. (2017). Performance appraisals and job satisfaction. The International Journal of Human Resource Management, 28(5), 750-774.

Karatepe, O. M. (2011). Procedural justice, work engagement, and job outcomes: Evidence from Nigeria. Journal of Hospitality Marketing \& Management, 20(8), 855-878.

Kaya, B., \& Karatepe, O. M. (2020). Does servant leadership better explain work engagement, career satisfaction and adaptive performance than authentic leadership? International Journal of Contemporary Hospitality Management, 32(6), 2075-2095.

Keating, L. A., \& Heslin, P. A. (2015). The potential role of mindsets in unleashing employee engagement. Human Resource Management Review, 25(4), 329-341.

Kim, W., Kolb, J. A., \& Kim, T. (2013). The relationship between work engagement and performance: A review of empirical literature and a proposed research agenda. Human Resource Development Review, 12(3), 248-276.

Kwon, K., \& Kim, T. (2020). An integrative literature review of employee engagement and innovative behavior: Revisiting the JD-R model. Human Resource Management Review, 30(2), 100704.

Lai, C.-Y., Hsu, J. S.-C., \& Li, Y. (2018). Leadership, regulatory focus and information systems development project team performance. International Journal of Project Management, 36(3), 566-582.

Lanaj, K., Chang, C.-H., \& Johnson, R. E. (2012). Regulatory focus and work-related outcomes: a review and meta-analysis. Psychological Bulletin, 138(5), 998-1034.

Lee, A. Y., Aaker, J. L., \& Gardner, W. L. (2000). The pleasures and pains of distinct self-construals: The role of interdependence in regulatory focus. Journal of Personality and Social Psychology, 78(6), $1122-1134$.

Lee, M. C. C., Idris, M. A., \& Tuckey, M. (2019). Supervisory coaching and performance feedback as mediators of the relationships between leadership styles, work engagement, and turnover intention. Human Resource Development International, 22(3), 257-282.

Li, X., Sanders, K., \& Frenkel, S. (2012). How leader-member exchange, work engagement and HRM consistency explain Chinese luxury hotel employees' job performance. International Journal of Hospitality Management, 31(4), 1059-1066.

Llewellyn, N., Dolcos, S., Iordan, A. D., Rudolph, K. D., \& Dolcos, F. (2013). Reappraisal and suppression mediate the contribution of regulatory focus to anxiety in healthy adults. Emotion, 13(4), 610615.

Lockwood, P., Chasteen, A. L., \& Wong, C. (2005). Age and regulatory focus determine preferences for health-related role models. Psychology and Aging, 20(3), 376-389.

Lucas, G. J., Knoben, J., \& Meeus, M. T. (2018). Contradictory yet coherent? Inconsistency in performance feedback and R\&D investment change. Journal of Management, 44(2), 658-681.

MacKenzie, S. B., \& Podsakoff, P. M. (2012). Common method bias in marketing: Causes, mechanisms, and procedural remedies. Journal of Retailing, 88(4), 542-555.

Mann, A., \& Harter, J. (2016). The Worldwide Employee Engagement Crisis. Washington, DC, USA Available at: http://www. gallup. com/businessjournal/188033/worldwide-employeeengagementcrisis. aspx.

McFarland, C., \& Miller, D. (1994). The framing of relative performance feedback: Seeing the glass as half empty or half full. Journal of Personality and Social Psychology, 66(6), 1061-1073. 
Messersmith, J. G., Patel, P. C., Lepak, D. P., \& Gould-Williams, J. S. (2011). Unlocking the black box: Exploring the link between high-performance work systems and performance. Journal of Applied Psychology, 96(6), 1105-1118.

Neubert, M. J., Kacmar, K. M., Carlson, D. S., Chonko, L. B., \& Roberts, J. A. (2008). Regulatory focus as a mediator of the influence of initiating structure and servant leadership on employee behavior. Journal of Applied Psychology, 93(6), 1220-1232.

Nishii, L. H., Lepak, D. P., \& Schneider, B. (2008). Employee attributions of the "why" of HR practices: Their effects on employee attitudes and behaviors, and customer satisfaction. Personnel Psychology, 61(3), 503-545.

Nitzl, C., Roldan, J. L., \& Cepeda, G. (2016). Mediation analysis in partial least squares path modeling: Helping researchers discuss more sophisticated models. Industrial Management \& Data Systems, 116(9), 1849-1864.

Noronha, S. F., Aquinas, P., \& Manezes, A. D. (2018). Is job performance better attributable to performance management system through work engagement? Indian Journal of Commerce and Management Studies, 9(1), 1-6.

O'Reilly, C. A., \& Chatman, J. (1986). Organizational commitment and psychological attachment: The effects of compliance, identification, and internalization on prosocial behavior. Journal of Applied Psychology, 71(3), 492-499.

Orth, M., \& Volmer, J. (2017). Daily within-person effects of job autonomy and work engagement on innovative behaviour: The cross-level moderating role of creative self-efficacy. European Journal of Work and Organizational Psychology, 26(4), 601-612.

Pichler, S. (2012). The social context of performance appraisal and appraisal reactions: A meta-analysis. Human Resource Management, 51(5), 709-732.

Piening, E. P., Baluch, A. M., \& Ridder, H. G. (2014). Mind the Intended-Implemented Gap: Understanding Employees' Perceptions of HRM. Human Resource Management, 53(4), 545-567.

Podsakoff, P. M., MacKenzie, S. B., Lee, J.-Y., \& Podsakoff, N. P. (2003). Common method biases in behavioral research: A critical review of the literature and recommended remedies. Journal of Applied Psychology, 88(5), 879-903.

Pombo, G., \& Gomes, J. (2018). How does work engagement mediate the association between human resources management and organizational performance? Problems and Perspectives in Management, 16(3), 63-79.

Poon, J. M. (2004). Effects of performance appraisal politics on job satisfaction and turnover intention. Personnel Review, 33(3), 322-334.

Pulakos, E. D., Mueller-Hanson, R., \& Arad, S. (2019). The evolution of performance management: Searching for value. Annual Review of Organizational Psychology and Organizational Behavior, 6(1), 249-271.

Rayton, B. A., \& Yalabik, Z. Y. (2014). Work engagement, psychological contract breach and job satisfaction. The International Journal of Human Resource Management, 25(17), 2382-2400.

Rhee, E. Y., \& Fiss, P. C. (2014). Framing controversial actions: Regulatory focus, source credibility, and stock market reaction to poison pill adoption. Academy of Management Journal, 57(6), 17341758.

Rosen, C. C., Levy, P. E., \& Hall, R. J. (2006). Placing perceptions of politics in the context of the feedback environment, employee attitudes, and job performance. Journal of Applied Psychology, 91(1), 211-220.

Sanders, K., \& Yang, H. (2016). The HRM Process Approach: The Influence of Employees' Attribution to Explain the HRM-Performance Relationship. Human Resource Management, 55(2), 201-217. 
Sanders, K., Yang, H., \& Li, X. (2017). HPWPs, HR commitment attributions and employee engagement: Considering power distance orientation. Academy of Management Proceedings, doi:10286. 10.5465/AMBPP.2017.10286abstract.

Sassenberg, K., Brazy, P. C., Jonas, K. J., \& Shah, J. Y. (2013). When gender fits self-regulatory preferences: The impact of regulatory fit on gender-based ingroup favoritism. Social Psychology, 44(1), 4-15.

Schaufeli, W. B., Bakker, A. B., \& Salanova, M. (2006). The measurement of work engagement with a short questionnaire a cross-national study. Educational and Psychological Measurement, 66(4), 701-716.

Schaufeli, W. B., Salanova, M., González-Romá, V., \& Bakker, A. B. (2002). The measurement of engagement and burnout: A two sample confirmatory factor analytic approach. Journal of Happiness studies, 3(1), 71-92.

Schneider, B., Yost, A. B., Kropp, A., Kind, C., \& Lam, H. (2018). Workforce engagement: What it is, what drives it, and why it matters for organizational performance. Journal of Organizational Behavior, 39(4), 462-480.

Sekhar, C., Patwardhan, M., \& Vyas, V. (2018). Linking Work Engagement to Job Performance Through Flexible Human Resource Management. Advances in Developing Human Resources, 20(1), 72-87.

Sharma, N. P., Sharma, T., \& Agarwal, M. N. (2016). Measuring employee perception of performance management system effectiveness: Conceptualization and scale development. Employee Relations, 38(2), 224-247.

Shin, Y., Kim, M., Choi, J. N., \& Lee, S.-H. (2015). Does Team Culture Matter? Roles of Team Culture and Collective Regulatory Focus in Team Task and Creative Performance. Group \& Organization Management, 41(2), 232-265.

Shrivastava, S., \& Rajesh, A. (2017). Managing performance better: advent of a new appraisal system at Infosys Limited. Human Resource Management International Digest, 25(3), 26-29.

Shrivastava, A., \& Purang, P. (2011). Employee perceptions of performance appraisals: a comparative study on Indian banks. The International Journal of Human Resource Management, 22(03), 632647.

Song, M., Meier, K. J., \& Amirkhanyan, A. (2020). Goal Ambiguity, Management, and Performance in US Nursing Homes. Administration \& Society, 52(8), 1170-1208.

Stewart, W. H., \& Roth, P. L. (2001). Risk propensity differences between entrepreneurs and managers: A meta-analytic review. Journal of Applied Psychology, 86(1), 145-53.

Stokes, N. M., Brooks S., Caulfield P., Wells J., P., Ann Rowland, C., \& Hall, R. D. (2013). Perceived unfairness in appraisal: engagement and sustainable organizational performance. EuroMed Journal of Business, 8(3), 195-208.

Thompson, E. R. (2007). Development and validation of an internationally reliable short-form of the positive and negative affect schedule (PANAS). Journal of Cross-Cultural Psychology, 38(2), 227242.

Tugade, M. M., \& Fredrickson, B. L. (2007). Regulation of positive emotions: Emotion regulation strategies that promote resilience. Journal of Happiness studies, 8(3), 311-333.

Tweedie, D., Wild, D., Rhodes, C., \& Martinov-Bennie, N. (2019). How Does Performance Management Affect Workers? Beyond Human Resource Management and Its Critique. International Journal of Management Reviews, 21(1), 76-96.

Vacharkulksemsuk, T., \& Fredrickson, B. L. (2013). Looking back and glimpsing forward: The broadenand-build theory of positive emotions as applied to organizations. In A. B. Bakker (Ed.), Advances in positive organizational psychology: Vol. 1. Advances in positive organizational psychology ( $\mathrm{p}$. 45-60). Emerald Group Publishing. 
Van De Voorde, K., \& Beijer, S. (2015). The role of employee HR attributions in the relationship between high-performance work systems and employee outcomes. Human Resource Management Journal, 25(1), 62-78.

Van Waeyenberg, T., \& Decramer, A. (2018). Line managers' AMO to manage employees' performance: the route to effective and satisfying performance management. The International Journal of Human Resource Management, 29(22), 3093-3114.

Volpone, S. D., Avery, D. R., \& McKay, P. F. (2012). Linkages between racioethnicity, appraisal reactions, and employee engagement. Journal of Applied Social Psychology, 42(1), 252-270.

West, J., \& Kelly, J. P. (2018). Performance Management Systems: How Companies are Rethinking People Development, 1-8. Retrieved from

Wilson, K. Y. (2010). An analysis of bias in supervisor narrative comments in performance appraisal. Human Relations, 63(12), 1903-1933.

Woodrow, C., \& Guest, D. E. (2014). When good HR gets bad results: exploring the challenge of HR implementation in the case of workplace bullying. Human Resource Management Journal, 24(1), 38-56.

Yeh, Y.-c., Lai, S. C., \& Lin, C.-W. (2016). The dynamic influence of emotions on game-based creativity: An integrated analysis of emotional valence, activation strength, and regulation focus. Computers in Human Behavior, 55, 817-825.

Zadra, J. R., \& Clore, G. L. (2011). Emotion and perception: The role of affective information. Wiley interdisciplinary reviews. Cognitive science, 2(6), 676-685. 


\section{APPENDIX: LIST OF MEASURES USED}

\section{PERFORMANCE MANAGEMENT SYSTEM CONSISTENCY}

1. The performance plan based on the performance management system gives a clear idea of what is expected of me to meet organizational goals.

2. The performance plan helps me focus my efforts through identification of goals (and/or behaviors/skills) relevant to meet organizational goals.

3. My manager and I update my goals frequently as business goals change.

4. The ongoing feedback during the performance cycle gives an accurate evaluation of how I am performing against planned performance.

5. During the year my areas for improvement are clearly pointed out to me.

6. I get the coaching I need during the year to achieve my goals (and/or improve my behaviors/skills) to achieve planned performance.

7. Annual feedback during performance review is an accurate representation of the ongoing feedback during the performance cycle.

8. My goals (behaviors/ skills) are accurately rated as part of the review process.

9. My annual performance review is very objective in assessment of my annual performance against planned performance.

10. Performance review results in an accurate performance rating.

11. My performance management outcomes (compensation, reward and/or recognition) are linked to my performance rating.

12. My annual performance review is directly related to my performance management outcomes (compensation, reward and/or recognition).

\section{PROMOTION REGULATORY FOCUS SCALE}

1. I take chances at work to maximize my goals for advancement.

2. I tend to take risks at work in order to achieve success.

3. If I had an opportunity to participate on a high-risk, high-reward project I would definitely take it.

4. If my job did not allow for advancement, I would likely find a new one.

5. A chance to grow is an important factor for me when looking for a job.

6. I focus on accomplishing job tasks that will further my advancement.

7. I spend a great deal of time envisioning how to fulfill my aspirations.

8. My work priorities are impacted by a clear picture of what I aspire to be.

9. At work, I am motivated by my hopes and aspirations. 


\section{WORK ENGAGEMENT SCALE}

1. At my work, I feel bursting with energy.

2. At my job, I feel strong and vigorous.

3. I am enthusiastic about my job.

4. I find my job really inspiring.

5. When I get up in the morning, I feel like going to work.

6. I feel happy when I am working intensely.

7. I am proud of the work that I do.

8. I am immersed in my work.

9. I get carried away when I am working.

\section{POSITIVE AND NEGATIVE AFFECT SCALE}

In my workplace, I generally feel...

\section{Positive affect}

1. Attentive

2. Alert

3. Inspired

4. Active

5. Determined

\section{Negative affect}

1. Afraid

2. Nervous

3. Upset

4. Hostile

5. Ashamed 